\title{
SOIL ORGANIC MATTER AND NUTRIENT STATUS OF SOME VEGETABLE GROWING SOILS IN MATARA DISTRICT
}

\author{
B C Walpola and S D Wanniarachchi \\ Faculty of Agriculture, University of Ruhuna
}

The main function of a soil from an agricultural perspective is to produce a bountiful crop with minimum inputs. Therefore, the maintenance of soil fertility and productivity is important to obtain a sustainable yield. Though, farmers prefer that their soil support . ideal crop growth, poor soil management practices adopted by them have caused a decreasing trend of yield continuously. Therefore, it is important to investigate the nutrient status of such soils and make recommendation for sustainable land management. This study was conducted to assess organic matter and nutrient status of selected vegetable growing soils in the Matara District, Sri Lanka.

Ten vegetable growing fields were selected and soil samples were drawn randomly from $0-15 \mathrm{~cm}$ depth. Soil samples were analyzed to determine $\mathrm{N}, \mathrm{P}, \mathrm{K}$ and organic matter content using standard methods and soil samples were also taken from a forest on the same soil type to compare cultivated and undisturbed soils.

Results revealed that the average soil N, P and $\mathrm{K}$ contents for the vegetable growing soil were $0.14 \%, 404 \mathrm{mg} / \mathrm{Kg}$ of soil and $106 \mathrm{mg} / \mathrm{Kg}$ of soil respectively, and the corresponding figures for the forest soil were $0.17 \%, 65 \mathrm{mg} / \mathrm{Kg}$ of soil and $30 \mathrm{mg} / \mathrm{Kg}$ of soil. The average organic matter content of the vegetable growing soils was $0.65 \%$, whereas the corresponding figure for the reference forest soil was $2.5 \%$. Results revealed that the average $P$ and $K$ contents of Vegetable growing soils were higher than the forest soil and possible reason may be the regular application of synthetic fertilizer to vegetable growing soils. Results further indicated that more than $50 \%$ samples collected from vegetable growing soils had $\mathrm{N}$ and organic matter contents below the average value.

According to the results, it can be concluded the most of the vegetahle growing soils in Matara District are considerably low in $\mathrm{N}$ and organic matter contents. Hence preventing soil erosion and sustaining or increasing soil organic matter levels by adding crop residues, compost and organic manures may be the most important practices that growers can adopt in managing soil nutrients status.

Proceedings of the Ninth Annual Forestry and Environment Symposium 2003 of the Department of Forestry and Environmental Science. University of Sri Jayewardenepura, Sri Lanka 